\title{
UMA AVENTURA NO TEMPO: REFLEXÕES SOBRE A PRODUÇÃO DE UM DOCUMENTÁRIO ETNOGRÁFICO E OS DESAFIOS DE UMA ETNOGRAFIA DA DURAÇÃO
}

\author{
Ana Luiza Carvalho da Rocha \\ Rafael Devos
}

A intenção que moveu a escrita deste ensaio é o de refletir, após 10 anos, sobre o processo de produção do vídeo-pesquisa A cidade e suas ruínas, que, nos primórdios do BIEV, se constituiu como um espaço paradigmático de "provocação" para os realizadores pensarem as poéticas sonoras e visuais na produção de novas narrativas etnográficas, em particular, de vídeos etnográficos sobre memória coletiva e patrimônio no mundo contemporâneo.

O documentário aqui apresentado resulta, por parte dos pesquisadores, de numa tentativa de reunir as imagens captadas no trabalho de campo realizado em Porto Alegre, de 1997 a 1998, sobre os casarios e os sobrados antigos, em processo de demolição ou abandono, os quais, diante deste compasso de espera, em sua maioria foram re-apropriados por moradores ocasionais que se tornaram os cuidadores destes lugares. A pesquisa de campo ocorreu em inúmeros bairros da cidade de Porto Alegre (Centro, Menino Deus, Cidade Baíxa, Bonfim, etc.) e, no processo de registro destas edificações desde seu lugar numa rua ou avenida, foi acompanhada do registro dos testemunhos de personagens que ali encontravam.

Para guiar esta viagem imersiva nos desígnios que acompanham as ruínas de antigos casarios e sobrados numa grande metrópole que se transforma no interior de uma tempo vertiginoso, habitam alguns destes casarios ${ }^{1}$ entrevistados ao longo do processo de etnografia, e para orientar nossos diálogos com seus moradores, a etnografia visual ( mais do que sonora) encontrou sua inspiração nas leituras da obra de G. Bachelard, A poética do espaço (1989) e a poética do devaneio (1993). Mais do que a realização de um vídeo-documentário, estamos aqui tratando de um documentário que se origina num vídeo-pesquisa, cujo principal sentido foi o desencadear, por meio do tratamento da imagem videográfica do fenômeno das ruínas e das forças de erosão e desagregação da matéria, um processo de reflexão sobre os modos de composição de narrativas sonoras e visuais sobre as feições da agitação temporal nas modernas sociedades contemporâneas, desde a perspectiva dos estudos da Antropologia urbana e da imagem.

\footnotetext{
$1 \quad$ Projeto Integrado de Pesquisa, com o apoio de Bolsa Produtividade em Pesquisa que reúne os SubProjetos, coordenado pela Profa. Dra. Cornelia Eckert e, sob minha coordenação, do Núcleo de Estudos sobre Culturas Contemporâneas pertencente ao Laboratório de Antropologia Social, do PPG Antropologia Social/UFRGS.
} 
Iniciamos o trabalho de campo, em 1997, profundamente inspirados pelo artigo de G. Simmel, Las ruínas ${ }^{2}$ (1934), onde o autor comenta que as ruínas abandonadas revelam, aquele que as contemplam, uma "passividade positiva”. Para o autor, na feição da ruína podemos observar que “o homem se faz cúmplice da natureza”, "permitindo a destruição" e "adotando uma maneira de agir que é oposta a sua verdadeira essência”! Todo “o encanto das ruínas consiste em que uma obra humana e percebida como si fosse exclusivamente um produto da natureza” (SIMMEL, 1934: 213214). Portanto, o documentário de que tratamos aqui não tinha, simplesmente , como tema a ruína de uma casa no universo, numa montanha (a casa alpina) ou num vale, senão que a ruína de antigos casarios e sobrados ao lado de grandes avenidas e prédios e edificações novas e modernas, paisagens urbanas cujas formas informes tinham sido objeto da tese de doutorado de um dos autores deste artigo $^{3}$. E, neste sentido, as ruínas no coração de uma grande cidade que se transforma, diferente da tragédia cósmica da casa no universo (BACHELARD, 1989b), opõe a “destruição da mão humana à destruição da natureza”.

Vamos refletir, portanto, neste ensaio sobre a produção de um documentários que tinha por intenção narrar o encanto melancólico das ruínas numa grande metrópole para desde aí etno grafar os processos em que a matéria encontra-se em luta contra as forças da do gestos humanos que a moldou, para gradualmente se independizar de suas formas. Além disto, nos interessamos ainda mais pelas ruínas habitadas, diferentes das ruínas abandonadas, que foram a maioria das casas que foram objeto do documentário, pois elas "tomam o aspecto problemático, inquieto, muitas vezes insuportável, de lugares onde a vida se retirou e que, sem dúvida, entretanto, aparecem como recintos e marcos de uma vida”(SIMMEL, 1934: 214).

\section{O argumento - as ruínas, a obra humana no estado informe da matéria bruta}

Para a realização da vídeo-pesquisa partimos da idéia simeliana de que a ruína representa o desequilíbrio entre a matéria e espirito no sentido de que a matéria moldada, que pesa e resiste ao espírito, finalmente se desprende de seus desígnios para retornar a indiferença. Neste ponto preciso, convocávamos, então, a ideia bachelardiana sobre os devaneios da imaginação criadora sobre a matéria, para pensar e refletir sobre as edificações humanas na cidade desde a perspectiva dos desafios humanos em enquadrar o tempo na forma estável de uma matéria (casas, sobrados, palacetes, aranha-céus). Estávamos pensando aqui as ruínas como re-inversão desta ordem cósmica patrocinada pelos devaneios aéreos veiculados pelo mito do Progresso. Seguindo os comentários de

2 Todas as citações mencionadas de G. Simmel neste ensaio resultam da tradução livre do espanhol para o português realizadas pelos autores. O ensaio aqui referido encontra-se no livro Cultura femenina $y$ otros ensayos. Madrid, Revista de Occidente, 1934.

3 Cf. A.L.C. da ROCHA, Le sanctuaire du désordre ou l'art de savoir-vivre des tendres barbares sous les Tristes Tropiques. Esthetique urbaine et mémorie collective au sud du Brésil, Paris V, Sorbonne, Université René Descartes, 1994, com orientação de M.. Maffesoli, junho de 1994. 
G. Bachelard (1989b) sobre os devaneios do repouso que habitam a imaginação material, e a proposta ainda incipiente de uma etnografia da duração, apostávamos que os jogos da memória se configuravam nas fronteiras entre a alma que aspira uma transcendência e o pensamento que se dirige à captura do mundo, sendo que a captura da imagem das ruínas de antigos casarios nos bairros de Porto Alegre nos ajudaram a compreender este fenômeno

O uso das cartelas com os pensamento bachelardianos, ao longo dos diversos momentos da narrativa documental, expressam, por exemplo, este processo de pesquisa do qual ela resultou. Um processo que ia da leitura de determinadas obras de G. Bachelard (1989a, 1898b, 1993, 1988a, 1988b) e de G. Simmel (1934) à produção de imagens videográficas que pudessem dialogar com algumas de suas ideias. Partimos, assim, dos desafios interpretativos que representam as ruínas para a modelagem da fuga do Tempo nas modernas sociedades complexas urbano-industriais. Um procedimento que nos conduzia a adoção da prática de produção de notas visuais de campo (sobre este procedimento falaremos mais adiante) como forma de captura do mundo das ruínas na e da cidade de Porto Alegre e, eventualmente, de registro de nosso contato com os seus guardiões destas moradas abandonadas, como é o caso de Andriana Bohrer Maciel, protagonista de nosso documentário. Um procedimento que incorpora a pratica do que, hoje, denominamos da etnografia da duração, e que vimos realizando desde 1998.

Logo, o vídeo-pesquisa A cidade e suas ruínas integrava parte dos registros documentais videográficos, recolhidos ao longo do projeto de pesquisa "Estudo antropológico sobre itinerários urbanos, memoria coletiva e formas de sociabilidade no mundo contemporâneo”, realizada entre os anos 1998-2004, com apoio da FAPERGS e CNPq). Em particular, parte do acervo das coleções etnográficas formadas a partir do subprojeto "Coleções etnográficas, memória coletiva e patrimônio etnológico”, que tinha por objeto o tema do patrimônio etnológico e a estética urbana nas modernas sociedades complexas, urbano-industriais.

As imagens que compõe o documentário acompanham a intenção dos realizadores de produção de uma narrativa audiovisual sobre os jogos da memória, inspirados nas reflexões proustiana sobre o tempo, numa alusão explicita a influência da tradição literária do romance e aquelas dos pintores de paisagem, da fotografia e do cinema para os estudos antropológicos e suas formas de representação do outro.

Neste ponto, entendemos que a etnografia audiovisual retomaria um espaço de representação singular que remonta, por mais bizarro que posso parecer, no mínimo, à tradição da ficção literária do Ocidente ${ }^{4}$ Em particular, em termos de muthos, estamos no interior de uma bacia semântica (G. DURAND, 1998, 100:120), e nela podíamos compreender que a imagem móvel abarca o

4 Cf. P. Ricoeur, Tempo e Narrativa II, SP, Papirus, p.38 o mito do Apocalipse, nas tradições do Ocidente ultrapassa o domínio da ficção literária atingindo os domínios “teleológico, através da escatologia 
deslizamento da poética do texto religioso (função figural do corpo da letra) para a poética do texto romanesco (função figurativa do corpo da letra) e onde, segundo J. Rancière (1995), o caráter figurativo do corpo da letra tenderia a apagar a sua dimensão figural, e ao apagá-lo conserva, entretanto, seu poder de atestar um corpo. ${ }^{5}$ Tratava-se, assim, esta experiencia que vínhamos passado de etnografia audiovisual, ou seja, como fruto de nossos tais deslizamentos da cultura da escrita e do espaço livresco e seu regime de representação, de onde tradicionalmente se filia a tradição da representação etnográfica em Antropologia.

Pensávamos, na ocasião, que a imagem móvel nos permitiria deslizar desde espaço de representação para outro, mas permanecendo ainda no campo das dos estudos do imaginário e da pesquisa sobre memória coletiva e patrimônio etnológico no mundo contemporâneo. Partíamos da ideia de que, se, na civilização do Ocidente, a leitura figural de um texto se realiza quando o corpo da letra encontra um corpo para provar sua verdade, na leitura figurativa da imagem móvel o corpo de verdade parece remete-la diretamente ao seu corpus tradicional de "verificação" das histórias, ou seja, enquanto verdade do corpo que encarna o verbo e sustenta sua evidência. (RANCIÈRE, 1995, p. 47:58), sendo ambas configurações simbólicas, em alusão ao poder formalizante das figuras do imaginário e seus procedimentos de expressão (DURAND, 1984:483). Ainda que sem ter uma ideia clara do processo conceitual mais formal de tudo sito que, hoje, descrevemos, esta perspectiva de pesquisa com etnografia audiovisual no âmbito dos estudos com memória coletiva e patrimônio etnológico no mundo urbano contemporâneo nos situava, no plano da dinâmica do imaginário, diretamente em dialogo com modalidade da narrativa fílmica adotada pelo estilo documental clássico das sinfonias metropolitanas, se formos pensar numa genealogia do gênero documental e o tema da metrópole moderno-contemporânea. ${ }^{6}$

Entre a equipe de realização, o vídeo-documentário, na época, significou o amadurecimento de uma discussão teórico-conceitual e metodológica, no plano das técnicas e procedimentos de pesquisa audiovisual na área da Antropologia urbana. Neste ponto, precisamente a retomada da controvérsia dos antropólogos pós-modernos a respeito do realismo na narrativa etnográfica em Antropologia clássica foi fundamental como ponto de partida para o processo de escrita videográfico do nosso percurso de investigação sobre as ruínas de casarios e sobrados em determinados bairros da cidade de Porto Alegre vivendo na época um processo intenso de retomada do debate, no plano das políticas públicas, sobre as questões patrimoniais de preservação de bens tangíveis e intangíveis.

judaico-cristã, histórico-político, através da ideologia imperial viva até a queda do Santo Império romanogermânico, e epistemológica, através da teoria dos modelos.

Para, J. Rancière, na linguagem figurada se esconde o livro da vida, e é, portanto, no interior da fabulação que o jogo figurado da linguagem faz funcionar a verdade do romance tanto quanto de um texto etnográfico.

$6 \quad$ A respeito ver M. H. C. A construção do imaginário urbano no documentário brasileiro contemporâneo, tese de doutorado defendida em agosto. 2008, Escola de Comunicação e Artes, Universidade de São Paulo, sob orientação Maria Dirá Genis Mourão. 


\section{Decisões e orientações metodológicas de investigação}

Atentos aos 'gêneros confusos' que podem resultar do uso da metáfora teatral para a apreensão da expressão estética que rege as formas de vida coletiva na cidade, tanto quanto o abuso da metáfora do texto para interpretar a ação simbólica que configura a teia de significados da cultura, o que se pretendeu com este vídeo foi essencialmente explorar os múltiplos campos de narrativas que finalmente "armam" a trama da etnografia do e no meio urbano como parte do 'fazer antropológico'. '

Na tentativa de enfrentar o desafio de narrar o tempo através das imagens móveis, no campo da produção de documentários etnográficos, nos apoiamos nas formas expressivas contidas em determinados conjuntos de conceitos da antropologia urbana e da antropologia visual8 tanto quanto recursos estilísticos da linguagem cinematográfica e literária. Nesse sentido, a produção recente dos cientistas sociais (ou ainda jornalistas, videomakers e cineastas) que produzem seus discursos utilizando-se das imagens em movimento tem apresentado narrativas que endossam as propostas de novas escrituras etnográficas. ${ }^{8}$

Motivados por procedimentos metodológicos e abordagens teóricas diversas, o vídeodocumentário A cidade e suas ruínas, portanto, encontrou inspiração nos "antropólogos visuais" e na sua conduta "em campo" e em suas práticas constantes de levarem suas câmeras a campo, realizando entrevistas, captando imagens da maneira como as pessoas vivenciam suas relações com o tempo e o espaço numa dada cultura.

Tendo como suporte dos rituais de aproximação entre os informantes e o antropólogo, o aparato tecnológico e o movimento/deslocamento da equipe em campo foi um aspecto essencialmente relevante na geração de indagações dos informantes ocasionais, habitantes da rua, interessados no sentido do registro de imagens de ruínas numa cidade voltada apenas recentemente ao tema do patrimônio artístico e histórico da cidade. Neste ponto, a realização do vídeo adota os pressupostos da construção de fazer antropológico dado a partir de um amálgama que inclui conceitos quotidianos empregados pelos habitantes/moradores de grandes cidades e conceitos científicos, onde a captação de imagens une-se ao ato interpretativo tanto do antropólogo como dos eventuais informantes que possa se dispor a dar seu depoimento durante a captação das mesmas.

O período da pesquisa de etnografia audiovisual foi, antes de tudo, uma etapa laboratorial, onde não só revisitamos as narrativas advindas de diferentes tradições da antropologia, da literatura e do cinema, como também buscamos o desenvolvimento de outras a partir de combinações e experimentos elaborados na interface entre arte e ciência. Nessa etapa laboratorial, seguiu-se um

\footnotetext{
7 A propósito, ver Geertz, C. 'Gêneros confusos’, in: El surgimiento de la Antropologia posmoderna, ${ }_{8}^{\text {op.cit. }}$

Conferir os trabalhos de Carelli, V. e Gallois, D. Asch, T., Macdougall, Goldenberg, S., entre tantos realizadores que produzem com a preocupação em traçar uma etnografia de culturas estrangeiras ou familiares a sua.
} 
processo de escolha do assunto a ser abordado dentro da cidade de Porto Alegre, o estudo e a composição da técnica narrativa a ser adotada, o registro e, finalmente, a edição das imagens escolhidas. Os registros de imagens utilizados foram, assim, considerados antes como "anotações visuais”, pois tinham a intenção de compreender o universo estudado: a cidade e as suas ruínas. ${ }^{9}$

Inevitável aqui alguns reflexões epistemológicas que integraram não só o trabalho do campo, mediado pelas 'notas visuais', mas as suas implicações na analise da composição narrativa que continham os registros das imagens segundo seu campo semântico particular. Mais importante que anunciar o 'estar ali' do etnógrafo, tratamos de investigar as possibilidades e os limites de se representar, através da composição formal da narrativa, a expressão de uma estética coletiva que reúne indivíduos e grupos urbanos e o contexto da cidade em mutação. Com a câmera no ombro, no lugar de um bloco de anotações, tendo como preocupação central o nosso próprio processo de objetivação do conhecimento etnográfico, a equipe confrontou-se seguidamente com as suas experiências subjetivas em campo. A câmera, nesse caso, foi concebida como um meio privilegiado na apreensão das informações tanto quanto na compreensão do processo de conhecimento em Antropologia uma vez que permitiu vislumbrar, de forma evidenciada, o sujeito que interpreta. ${ }^{10} \mathrm{~A}$ captação de imagens foi encarada um instrumento de síntese cognitiva de apreensão estética do universo das ruínas em Porto Alegre - tanto do dado inteligível quanto do dado sensível da realidade investigada, portanto, como instrumento de expressão estética e de construção de significados. Como parte integrante da pesquisa, tais experimentos etnográficos em "territórios-mito" da cidade de Porto Alegre, explorou-se as formas de seus "cenários-tipos", seus "personagens-tipo", suas "situações-tipo" no jogo da tessitura da temporalidade das intrigas que encerram.

\section{Notas de campo, notas visuais: a pesquisa etnográfica nas modernas sociedades}

\section{complexas}

A pesquisa em Antropologia instrumentalizadas por técnicas e procedimentos de registro das obras da cultura por meio de imagens técnicas (analógicas, eletrônicas e digitais não é novidade para a etnografia, ela tem já um terreno fértil de investigação no mundo, e em particular no Brasil, nas últimas décadas. Seguimos, portanto, esta tradição da pesquisa antropológica no contexto das modernas sociedades complexas onde o uso dos registros sonoros e visuais da obras da cultura tem sido fonte constante de reflexão entre os antropólogos urbanos e, mais recentemente, para o caso da construção de conhecimentos em torno da memória e do patrimônio nas e das grandes metrópoles contemporâneas.

\footnotetext{
9 A propósito, ver Satt, M.H. Circularidades e Superfícies: leituras videográficas das imagens batuqueiras. Dissertação de Mestrado em Multimeios, UNICAMP, 1995.

10 Clifford, J. 'Sobre l'autoridad etnográfica', in: El surgimento de la Antropologia posmoderna, Reynoso, C. (org.), Mexico, Gedisa, 1991.
} 
Na realização do documentário A cidade e suas ruínas aliamos a estas preocupações uma interrogação do uso do vídeo como parte dos recursos narrativos da prática antropológica de grafar as culturas humanas, advindos do paradigma interpretativista em Antropologia, e a ela ${ }^{11}$ soma-se as contribuições proporcionadas pelos estudos antropológicos das tradições literárias e cinematográficas para a construção da representação etnográfica.

Neste ponto, pelo caráter fortemente laboratorial do vídeo-documentário Cidade e suas ruínas, é que se optou por denominar as imagens oriundas da pesquisa de campo de notas videográficas, referindo-nos aqui ao uso que M.H. C. Satt (1995) fez do conceito de "notas cinematográficas", elaborado por André Leroi-Gourhan ${ }^{12}$ ao considerar o personagem do documentarista social que filma fazendo anotações visuais ${ }^{13}$.

Partindo, portanto, da observação das "anotações visuais" (resultando na edição de pequenos documentários etnográficos) e da pesquisa com construções narrativas, executadas no trabalho de campo, é que este vídeo, finalmente, pode ser visto como parte da intenção que move o subprojeto mencionado, “Coleções etnográficas, memória coletiva e patrimônio etnológico”. Ou seja, a pesquisa com documentários etnográficos orientados para o tema dos jogos da memória no mundo urbano contemporâneo. ${ }^{14}$ Tratava-se de explorar o momento vivido pela comunidade urbana local que orientariam a pesquisa de campo nos bairros da cidade de Porto Alegre, atingidos por reformas urbanas, tanto quanto o tratamento documental de registro etnográficos, na modalidade de acervos

11 Cf. Cardoso de Oliveira, R. A categorias de (des)ordem e a pós-modernidade da antropologia, in: Segundo o autor, o antropólogo classifica os “paradigmas racionalista, e estrutural-funcionalista e culturalista, orientadores respectivamente da École Française de Sociologia, da British School of Social Anthropology e da American Historical School of Anthropology”. O quarto domínio dessa matriz disciplinar, segundo o autor, fica por conta do paradigma hermenêutico do qual fazem parte a Antropologia interpretativa, “dialógica”, “crítica” e "pós-moderna”. Cardoso de Oliveira acredita que a coexistência dessa nova antropologia com s tradicionais traz uma "uma tensão que pode ser estimuladora de novos experimentos".

$12 \quad$ Em 1948, André Leroi-Gourhan escreveu um artigo intitulado "Le film ethnographique existe-t-il?". Nele, o etnólogo afirmava que o filme de pesquisa compreende dois tipos. O primeiro, classificou como "notas cinematográficas", rodadas no dia-a-dia sem planos pré concebidos. O segundo que chamou de "filme organizado", é produzido sem preocupações comerciais, mas suscetível de interessar o grande público. Cf. HEUSCH, Luc de. Cinéma et sciences sociales: panorama du film ethnographique et sociologique. Paris, 1962. p. 18. Unesco

13 A tendência de ir a campo sem um planejamento pré-concebido obteve seguidores. A antropóloga visual Claudine de France, por exemplo, sugere que "o registro cinematográfico, suporte da observação diferida das imagens, torna-se o ato primeiro da pesquisa. O filme abre a investigação". Cf. FRANCE, Claudine. Cinéma et anthropologie. Paris, Editions de La Maison des Sciences de L'Homme, 1982. p. 305 309. Contudo, diferentemente da proposta experimental e plural em relação aos procedimentos metodológicos que desenvolvo aqui, sua teoria estabelece normas precisas sobre o que registrar - "técnicas rituais, materiais ou corporais" - e como fazê-lo.

14 Tendo em vista que o nosso objetivo era o estudo de técnicas narrativas para a construção de novas propostas de documentários etnográficos da e na cidade, a reflexão e manipulação das imagens foi uma constante em nosso processo de trabalho. Portanto, as anotações visuais as quais nos referimos envolveram tanto o momento anterior de reflexão e pesquisa de diferentes propostas narrativas, como o posterior na edição, onde, grosso modo, concluímos um recorte, dando forma final ao relato que denominamos notas visuais. 
de coleções, tendo como tema de investigação o patrimônio etnológico do mundo urbano contemporâneo. 15

A opção metodológica do desenvolvimento dos experimentos etnográficos que deu origem ao vide-o A cidade e suas ruínas, incorporando, ao processo de produção do documentário etnográfico, a compreensão antropológica que emerge da imersão do etnógrafo na realidade cotidiana de uma grande metrópole, implica um projeto que se constrói por etapas decorrentes do próprio percurso da investigação. Um percurso concebido em diferentes momentos que ora se alternavam, ora entrecruzavam-se, tendo como objetivo primeiro a construção de formas narrativas no e do mundo urbano. Assim, o produto acabado de cada processo experimental, foi composto em 3 etapas distintas, respectivamente, a da pré-produção (criação de pré-roteiro de etnografia visual associada a ida à campo exploratória), a da produção (a realização de notas visuais, decupagem, analise e acervo das imagens) e, finalmente, a da pós-produção, com a construção de roteiro de edição da obra videográfica acabada. Cada uma das fases de pesquisa associada à preocupação de retratar estilisticamente a feição estética configuradora de uma cultura urbana e o fenômeno da memória coletiva que encerram as formas de vida social em certos bairros de Porto Alegre.

Abordar a estética da desordem ${ }^{16}$ das formas que reveste a vida urbana, em constante processo de destruição e criação nas metrópoles contemporâneas, como objeto de investigação do tempo e da duração em sociedades complexas, representou, para a realização do documentário, uma preocupação dos pesquisadores do BIEV com o paradigma estético ${ }^{17}$ na interpretação das figurações da vida urbana portalegrense. Trata-se aqui, portanto, de se investir numa pesquisa que contempla como fonte de investigação a própria retórica analítica do pesquisador em seu diálogo com o seu objeto de pesquisa - a Cidade e seus habitantes - bem como a estética dos arranjos sociais da vida urbana de Porto Alegre e do territórios-mitos onde seu corpo coletivo se enraíza.

\section{O documentário, muthos e poïesis: o ser do etnográfico"no"mundo}

Desde o começo, para a realização da pesquisa, aceitamos como desafio que todo o documentário é etnográfico se, através dele, o antropólogo consegue "mimetizar” o processo através do qual ele atingiu a compreensão aproximativa com o fenômeno investigado (e do qual faz é parte

15 A intenção incial que movia este projeto, e que irá inspirar, posteriormente a criação do BIEV, Banco de Imagens e Efeitos Visuais, era, portanto, o estudo das possibilidades narrativas da imagem videográfica para o tratamento do fenomeno da agitação temporal e do sacrificio da matéria associada a transformação da paisagem urbana portoalegrense em fins da década de 90, do século passado.

16 A propósito ver Rocha, Ana Luiza C. da “ A irracionalidade do belo e a estética urbana no Brasil”. In: Territórios do cotidiano, uma introdução a novos olhares e experiencias. Zila Mesquita \& Carlos Rodrigues Bradão (orgs). Porto Alegre/Santa Cruz do Sul, Rio Grande do Sul, Ed. da UFRGS/Ed. da UniSC, 1995.

17 Alinhamo-nos aqui ao paradigme estéticia defendido por M. Maffesoli para o estudo da memória respiratória dos espaços urbanos das grandes metropoles contemporâneas, e resumido no artigo seminal « Le 
integrante). Nossa idéia era que, numa perspectiva estética e formista ${ }^{18}$, a obra etnográfica que nós produziríamos traria o desafio de instalar no espectador a perturbação de sua condição de habitante de uma grande metrópole, desde a fruição estética que as ruínas e as suas formas lhe possibilitariam, re-configurando para si a experiencia vivida por nós ao longo do trabalho de campo.

Para isto tratava-se da ideia da construção de uma obra etnográfica sobre a cidade e suas ruínas explorando-se visualmente a distensão temporal que elas evocam na paisagem urbana das grandes metrópoles, isto é, como metáfora da experiência temporal humana. Ao invés de ater-nos no processo de representação cronológica do tempo no tratamento das ruínas, como parte integrante das vidas/escolhas humanas, através de uma sucessão de "agoras abstratos" em que história do lugar seria remontada, progressiva e linearmente, pretendíamos, no campo diegético do documentário, romper com esta perspectiva, tratando a paisagem urbana portalegrense desde um campo complexo de operações interpretativas onde as imagens de diferentes ruínas se sobrepõem umas às outras.

Tomando-se obras e artefatos da cultura urbana portalegrense tais como casas, casarios, sobrados e palacetes, suas ruas e esquinas, em estado de "ruínas", assim como a retorica social sobre eles, como fonte de investigação, por meio das 'anotações visuais de campo', nos comprometíamos com uma reflexão em torno do 'giro interpretativo' que resulta a fabricação de imagens como parte do trabalho do antropólogo em sua própria cultura.

Por um lado, teríamos que dar atenção a perspectiva da poieses ${ }^{19}$ que rege as formas de ser social nos territórios de uma grande metrópole, observando as ruínas como parte do trajeto antropológico do qual resulta a personalidade ética e o comportamento estético de seus moradores. ${ }^{20}$ Por outro, atentos a teoria da ação simbólica acoplada à perspectiva do drama (aqui visto como fábula $^{21}$ ou muthos ${ }^{22)}$ na configuração das tramas da vida metropolitana, tratávamos de pensar novas narrativas etnográficas sobre estética urbana e memória coletiva no mundo contemporâneo. Em especial, encontrávamos inspiração nos estudos da hermenêutica ricoeriana para a pesquisa com a produção de documentários etnográficos sobre memória coletiva e patrimônio etnológico no e do meio urbano. Uma hermenêutica que concebe o etnógrafo não apenas como interprete do 'nativo' mas como intérprete de si-mesmo, tendo em vista o lugar que ocupa no diálogo com os seus sujeitos

Paradigme esthétique : la sociologie comme art », publicada na Revue Sociologie et sociétés, vol. $17, \mathrm{n}^{\circ} 2$, 1985

18 Ver a respeito o artigo de M. Maffesoli, "Le paradigme esthétique: la sociologie comme art". In: Sociologie et sociétés, vol. $17, \mathrm{n}^{\circ} 2,1985$, p. 33-40, onde o autor vai postular o lugar estratégico da cultura e todo o seu cortejo de símbolos como parte do jogo interpretativo das sociedades humanas.

$19 \quad$ Ricoeur, P. Tempo e Narrativa. Vol I, SP, Papirus, 1994, pp. 55-76.

20 A infuência da obra de P; Sansot, orientando de G. Bachelar sobre as formas sensíveis de vida social e a poética da cidade são aqui referencias a serem mencionadas Les gens de peu, Paris, PUF, 1992, Le goû de la converstion, Paris, Desclée de Brouwer, 2003, Les formes sensibles de la vie sociale, Paris, PUF, 1986, Poétique de la ville, Klinckieck, Paris, 1997, e, finalmente, Variations paisagères, Paris, Klincksieck, 1983.

$21 \quad$ A propósito ver Rancière, J. Políticas da Escrita. São Paulo: Editora 34. 1995.

22 A propósito ver Ricoeur, R. Tempo e Narrativa. Vol I, SP, Papirus, 1994, pp. 85-133 
de pesquisa, até o diálogo que ele constrói consigo mesmo, quando constrói a sua descrição etnográfica.

Sob este ponto, em particular, a aproximação do processo de formação dos conceitos em Antropologia com aqueles oriundos do campo da narrativa (histórica ou literária), e sobre as quais mencionamos anteriormente, permite ao etnógrafo documentarista a sua integração espaço-temporal nas formas de composição que assumem as "artes de contar" para outrem que não seus pares da academia, fazendo-o refletir sobre as diferentes camadas de tempo que encerra uma narração na vida ordinária e as suas diferentes modalidades de compor uma intriga.

O emprego de registros visuais e sonoros como lugar da construção dos experimentos etnográficos permitiu, finalmente, com este vídeo um estudo mais detalhado do "circulo hermenêutico” que configuradora a tessitura do texto etnográfico. O que o vídeo propõe, finalmente, é a possibilidade não apenas do registro, no tempo, do processo de investigação do antropólogo no mundo urbano, mas da sua participação na retórica do tempo nas modernas sociedades complexas. Ele refletiria, o que vamos denominar, alguns anos mais tarde, das dilaceramentos do antropólogo na figura do narrador ${ }^{23}$, ao tratar as ruínas de uma cidade como metáfora da crise nas modernas cidades urbano-industriais e o registro da sua expressão estética.

Para nós, tratava-se de operar, no plano da produção de um documentário etnográfico, com a assertiva segundo a qual o ato de narrar uma história, no plano da recriação de uma intriga, explora inúmeros dispositivos de "domesticação" simbólica do tempo, dos quais tanto o etnógrafo quanto o grupo/comunidade do qual se gera a obra documental não podem escapar. Isto exige, da parte daquele que narra, o domínio da representação espacial do tempo como um fenômeno granular e cumulativo, uma vez que a narrativa se realiza através da organização de um lento processo de consolidação temporal que tem diferentes eixos de espaço-temporais sobrepostos.

Levando-se em conta o espaço fílmico e o espaço diegético na construção do espaço de representação do tempo para a narrativa etnográfica sobre as ruínas, no coração dos jogos da memória de certos bairros da cidade de Porto Alegre, tem-se o desafio de fazer concordar o trajeto do documental com os atos sociais das quais elas derivam. Tal concordância não é substantiva, não está nas coisas documentadas, mas na linguagem de símbolos onde elas (as coisas documentadas) são geradas, cujos registros operamos ${ }^{24 .}$ s obre isto iremos tratar mais tarde ao discutirmos os limites do pensamento deleuziano ao encerrar o tema da narrativa veraz e da narrativa de simulação na polêmica da imagem-tempo e da imagem-ação, respectivamente.

23 Cf. ECKERT, Cornelia \& ROCHA, Ana Luiza C. da “O antropólogo na figura do narrador”. In: Habitus, Revista do Instituto de Pré-História e Antropologia. Universidade Católica de Goiânia. Goiânia, GO, Ed. da UCG. Vol. 1, n. 2, jul./dez 2003.

A respeito ver Cassirer, E La philosophie des formes symboliques. Vol. I, II III. Paris, Editions de Minuit, 1972. 


\section{A imagem móvel e o processo de realização de um documentário etnográfico}

Retornando ao documentário A cidade e suas ruínas, foi a partir dos estudos da tríplice mimese na obra Tempo e Narrativa, de P. Ricoeur (1994) e da obra de G. Durand (1984; 1964), aliados à prática do registro das imagens sonoras e visuais em vídeo, oriunda da produção do documentário Arqueologias urbanas - Memórias do Mundo, que desenvolvemos o experimento etnográfico narrativo que acompanha a realização do vídeo aqui analisado. Nossa intenção inicial era combinar técnicas etnográficas clássicas de registro audiovisual, explorando o conteúdo figurativo dos enquadramentos, planos e sequências, tanto quanto, por meio do tratamento documental do gesto e da aventura da matéria sobre o sujeito da figuração (o etnógrafo), gerar no espectador novas reflexões sobre as figurações da memória coletiva no meio urbano de Porto Alegre.

No documentário, podemos atentar que, não por acaso, a imagem móvel, na condição de registro etnográfico produzido ao longo do trabalho de campo, em certos bairros da cidade de Porto Alegre, se apresenta incompleta ou defeituosa tecnicamente tendo em vista o aspecto predominantemente laboratorial que ela conserva, por integrar um lento processo de pensar as ruínas desde a decomposição/recomposição de sua matéria. Imagens cuja imperfeição trata, precisamente, das experiências dos realizadores com a paisagem urbana de tais ruínas no interior de ruas e avenidas de uma grande metrópole. A preocupação era explorar o uso de técnicas e procedimentos metodológicos oriundos da prática da pesquisa etnográfica com base no uso dos recursos audiovisuais ,para fins de expressão do olhar do antropólogo sobre o perfil de sua própria cidade, desde a tragédia das forças construtivas ou destruidoras da natureza sobre suas edificações.

Tentávamos articular a construção do roteiro de trabalho de campo por meio de notas sonoras e visuais ao tempo da entrada em campo, do encontro etnográfico, no tempo da narrativa videográfica propriamente dito, e que reuniria o registro audiovisual à própria situação desde onde ele nascia. ${ }^{25}$ Os efeitos gerados nas imagens, e que foram sendo explorados ao longo da pesquisa, faziam sentindo, na época, com nossa intenção de pesquisar o gestual expressivo do etnógrafo através do qual trabalha a matéria da imagem, em seu trabalho de campo, a ponto de desfigura-la, suavizando ou acelerando os encadeamentos narrativos, suspendendo ou sobrecarregando suas significações - uma espécie de estilização do olhar do etnógrafo em campo, capaz de desvendar a ação dramática contida na vibração da lenta erosão de uma ruína.

\section{Opsis e muthos, seus contextos expressivos!}

$25 \quad$ Ver a respeito ROCHA, Ana Luiza C. da “Antropologia visual, um convite à exploração de encruzilhadas conceituais”. Cornelia e MONT-MÓR, Patrícia (orgs). In: Imagem em foco, novas perspectivas em Antropologia. Porto Alegre, PPGAS/UFRGS e Ed. Da Universidade, 1996. 
A diferença entre a logica das ações encadeadas pela escrita dos diários de campo e e a do registro das notas sonoras e visuais era aqui problematizada a partir da teoria dos regimes da arte elaborada por J. Rancière (2001) o da arte representativa e da arte estética. Ainda não compartilhemos com o autor sua ideia da arte hierarquizada nos moldes aristotélicos - pautada na sobredeterminação do muthos sobre o opsis-, ponderávamos que sua teoria sobre dos regimes da arte traziam para nós questões relevantes para se refletir as possibilidades da produção de narrativas etnográficas sonoras e visuais e seu dialogo com a cultura da escrita que fundaria o campo disciplinar da Antropologia como “ciência”.

Num e noutro caso, compartilhávamos com o autor a ideia de que a máquina, a técnica e a tecnologia não disponibilizam estorias/histórias a serem narradas senão que elas estão a serviço de uma inteligência narrativa (RICOEUR, 1994), e que, complementaríamos nós, tem as estruturas da imaginação criadora como seu grande reservatório. ${ }^{26}$ A partir dessas reflexões, a intenção é resgatar aquilo que a imagem móvel nos revela como documental, só que dentro de outro espectro, ou seja, nos termos de presença do sensível, e não apenas pura passividade de um poder expressivo do etnógrafo e de sua "técnica audiovisual”, independente da obra e de sua significação para o outro. ${ }^{27}$

Para que possamos avançar vamos retomar alguns pontos chaves de nossa investigação sobre novas narrativas etnográficas da qual resultou o vídeo A cidade e suas ruínas. Um deles seria pensar "as propriedades dos espaços e os possíveis do tempo" (RANCIÈRE, 2005 : 15-16) da imagem móvel no tratamento documental da memória coletiva nas modernas sociedades complexas. Nos apoiando nos comentários de J. Rancière (2001), que abre uma importante discussão sobre dois dos três paradigmas da $\operatorname{arte}^{28}$. Em particular, vale mencionar suas críticas ao domínio estético das artes (pura criação, sem regras, sem modelos) e a forma como ele impôs uma desfiguração dos antigos sistemas de representação. Comparando o antigo regime da representação (da arte

26 Atentos as diferenças entre os autores identificamos pontos de contato na obra de J. Rancière, P. Ricoeur 1994) e G. Durand uma vez que todos eles reconhecem, direta ou indiretamente, o lugar que G. Durand atribui a narrativa , ou seja, se conhecer no tempo da narração ou da fábula (muthos) - o tempo literário, cinematográfico, fotográfico, etc.- é conhecer-se no interior de uma sequencia de fixações nos espaços de estabilidade do Ser, de um ser que não quer desaparecer, que , no passado, quando vai em busca do tempo perdido, deseja antes de mais nada suspender o vôo do tempo.

$27 \quad$ Retomados desde a otica dos estudos de G. Durand, Archétypes et beaux-arts (1989) e Fygures mythiques et visages de l'oeuvre (1979b), podemos concordar com J. Rancière ao afirmar que ambos os processos relacionam-se ao tema da desfiguração da imagem e do imaginario advindos das catastrofes metafísicas das quais nasce o Ocidente moderno e a figura do homem da cvilização em detrimeno da figura do homem da tradição, cf. G. Durand, Science de l'homme et Tradition ( 1979a). Num e noutro dos regimes, estariamos no no registro dos regimes do imaginario durandiano e de suas estruturas, princípios lógicos, simbolos e schèmes, cf. G. Durand, Les structures anthropologiques de l 'imaginaire (1984). Outros autores e obras importantes para este campo de reflexão que adotamos é L. Ferry, Homo Aestheticus/A Invenção do Gosto na Era Democrática. São Paulo: Editora Ensaio, 1994, e, certamente, M. Foucault, As palavras e as coisas. São Paulo, Martins Fontes, 1966.

${ }_{28}$ A tese do autor é de que existiam três grandes regimes de identificação da arte: o "regime ético das imagens", o "regime poético" e o "regime estético das artes". Em particular, nos interessa aqui suas análises a respeito dos dois principais discursos sobre a modernidade estética, deixando-se de lado a sua polêmica noção de vanguarda. 
tradicional) da arte da palavra com a literatura, na modernidade estética (em seus dois discursos da autonomia da arte e da sua rejeição), o autor, assinala que, por exemplo, o antigo regime se vale da passividade do visível (o corpo mudo e falante da letra) em sua operação com o sensível para atingir seu corpo de verdade. O cinema, na mesma direção, para pertencer ao regime estético das artes, precisa inverter este processo, e afastar da "vida” nos trabalhos com a imagem móvel. Contrariando a passividade do visível, a imagem móvel necessita atravessar o visível (e até mesmo a palavra) para atingir sua condição de fábula cinematográfica. Assim, a criação de uma dramaturgia no cinema implica sempre um distanciamento sobre o dispositivo cinematográfico. Com isto, a "escrita cinematográfica” para atingir o plano da dramaturgia investe no espaço diegético dos cenários, dos diálogos entre os personagens, dos papéis e da caracterização dos mesmos, dos adereços e do figurino para atingir plenamente, com a retórica visual transmutando-os em sentido figurado.

Podemos assinalar esta ideia mais claramente para o caso das análises dos documentários contemporâneos, sob a influência da obra deleuziana, de que o gênero documental engajado no ato de narrar as grandes metrópoles contemporâneas teria por compromisso mimetizar, em suas formas de contar estória através do encontro maquínico com o outro e a cidade, a experiencia urbana banal e ordinária tida como desestabilizante, híbrida e intersticial. Geralmente, nestas abordagens, se perde de perspectiva a pertença, no plano do imaginário, do gesto do documentarista em relação a cidade como objeto a ser documentado, nos moldes de uma bacia semântica. Ou seja, de que tal gesto encontra-se perfeitamente integrado subjetivamente a paisagem urbana que o olho da câmera procura retratar, e que desde o exterior (objetividade) procura restaurar, realizando plenamente os termos de uma tragédia da cultura, tão bem apresentados por G. Simmel $(1934)^{29}$. O etnógrafo ao adotar os recursos audiovisuais herda, portanto, esta a política do sensível, na qual ocupa um lugar. O exercício etnográfico com o uso da imagem móvel, na ocasião da experiencia com o documentário A cidade e suas ruínas trazia esta polemica, ou seja, aprender a estética audiovisual tendo em vista sua pertença a forma particular de se experiencias, na modernidade, esta distribuição dos tempos e dos espaços, do visível e do invisível, da palavra e do ruído.

Neste ponto, admitíamos que este exercício reflexivo residia em tudo aquilo que víamos durante a experiencia de trabalho de campo e sobre tudo o que podíamos falar daquilo que víamos nos bairros de Porto Alegre, isto é, a cidade desde sua paisagem de ruínas. Obviamente, levando-se em conta nossa competência em "ver” segundo a qualidade daquilo que nós, como antropólogos urbanos, tínhamos a dizer.

29 Novamente aqui a referencia é a tese de M. H. C. SATT, A construção do imaginário urbano no documentário brasileiro contemporâneo, tese de doutorado defendida em agosto. 2008, Escola de Comunicação e Artes, Universidade de São Paulo, sob orientação Maria Dirá Genis Mourão, onde a autora nos permite perceber claramente este processo ao tratar do documentario sobre as cidades brasilerias, nas ultimas décadas, produzidos no Brasil. E onde assinala as diversas modulações das relações de proximidade e distancia que o documentarista/aquilo ou aquele que é objeto/sujeito de seu registro e a situação, pautados desde onde esta interação acontece - a cidade moderno-contemporânea. 
Portanto, retraduzindo este tema para o caso da etno-grafia sobre esta distribuição dos tempos e dos espaços em sociedades complexas, teremos uma situação mais crítica Na escrita etnográfica clássica, geralmente processadas no interior das ditas sociedades "primitivas" ou "simples", o antropólogo esforçava-se por expressar o trabalho ativo da experiencia do encontro etnográfico no corpo da letra, muda e falante, tornando-se o seu futuro-passivo; nela o privilegio das artes de narrar, seja em sua capacidade de desembaraçar-se de todo o vestígio da presença do antropólogo-autor (dada na passividade do olhar do etnógrafo em campo, invisível, exposto as ações ordinárias do fenômeno por ele pesquisado), seja por seu desejo de realizar o seu contrário (a autoridade etnográfica obtida precisamente no estilo de escrita que subverte o olhar passivo do antropólogo-autor), cinematográfica, o olhar (opsis) ganha terreno em relação ao ato de narrar (muthos)

\section{O dinamismo do trajeto das imagens nas artes de contar estórias}

Com este objetivo de reunir um "dispositivo técnico de produção de imagens visíveis e uma maneira de contar histórias” (RANCIÈRE, 2001:11), concebemos, na realização do documentário A cidade e suas ruínas, as propriedades da "arte das imagens móveis” a partir do encadeamento entre as mimeses apresentadas por P. Ricoeur (1994). Esboçamos, assim, ainda que grosseiramente, a tríplice mímese ricoeriana à situação da pesquisa etnográfica. Ou seja, o destino de um tempo préfigurado (campo da experiência pratica do antropólogo com a própria cidade e o fenômeno a ser etnografado, que "esta lá” e que precede a tessitura da intriga da própria etnografia) em um tempo refigurado (da experiência temporal do etnógrafo e que sucede às situações vividas por ele em campo), pela mediação de um tempo configurado (que transcorre no momento da re-narração do tempo vivido do "lá” no “aqui”, do presente no espaço da narração fílmica da qual participa o espectador.

Seguíamos, ainda timidamente, diferente do que acontecerá ao longo dos anos, a assertiva de J. Rancière (2001) para quem é somente em nome da arte que nós podemos associar um dispositivo técnico a este ou aquele tipo de fabula (muthos), ou nos termos de G. Durand (1984) aplicar a arte distinções segundo "eras míticas psico-sociais”. Isto é, o “cinema, como a pintura e a literatura não são simplesmente o nome de uma arte onde os procedimentos seriam derivados de sua matéria e de seu dispositivo técnico próprio”. Com isto, as formas de se contar uma estória com imagens visíveis não se reduziria ao automatismo da "máquina" que as produz (através da captura infinita de movimentos) e a técnica de inscrever numa matéria a intimidade das coisas. ${ }^{30}$ A essência pura da

$30 \quad$ O autor se refere ao principio da identidade do ativo (agenciamento dos conflitos de vontades e das ações, das mudanças de sorte) e do passivo (passividade do visivel), e que traduz o equipamento técnico em sua produção de imagens visiveis, como parte de uma revolução estética, a "cinematográfica”. Uma estética que, para se manter fiel a ela mesma, necessita se construir no interior de uma dramatugia que contraria seus “poderes naturais”, num apelo expressões teatrais e da literatura, por exemplo, as quais os contrariam na forma 
imagem visível (e que abordaremos mais tarde desde a crítica a cisão entre imagem-ação e imagemtempo no pensamento deleuziano) é uma fábula (ficção racional) ${ }^{31}$, que se apoia em outra, a do melodrama filmado, que por sua vez remonta as convenções dramáticas do teatro que a "era cinematográfica” herda! ${ }^{32}$

A intenção de pesquisa com as ruínas era, assim, abordar, o momento da própria instauração da pesquisa etnográfica audiovisual, tendo a cidade como voz narrativa da memória coletiva e do patrimônio da vida urbana local, desde a sensorialidade da imagem móvel até a sua fragmentação visual, desconstruindo-a como resíduo da consciência. No plano da narrativa etno-gráfica, impunhanos o desafio de reunir o “documental” (a verossimilhança da ação) e o "ficcional” (da verdade sem significação da vida), valiamo-nos aqui da teoria da dialética da tríplice mimese (pré-figuração, configuração e re-configuração) abordada por P. Ricoeur (1994, 1995). Ao apostar na dimensão fabulatória da imagem móvel e como ponte para a interpretação do tempo, na interioridade do sensível que configura a matéria das ruínas, nos uníamos às reflexões bachelardiana sobre a dialética da duração e e a poética do espaço, para pensar a ritmanálise que comporia a morada solta no universo. Em particular quando o autor apresenta a dialética da duração como resultante da sobreposição consolidada de dois registros temporais, o tempo vivido e o tempo pensado (BACHELARD, 1989). Da mesma forma, nos alinhávamos aos estudos de G. Durand (1984, 1989, 1979 ) sobre as artes e a explosão das formas de comunicação e difusão de imagens (as mídias) como configuradoras da psiquê do homem ocidental, ou ocidentalizado, e dos seus níveis de representação como parte dos estudos do imaginário.

No plano da compreensão narrativa, o "potencial hermenêutico" das "notas visuais de campo” envolveria, para os realizadores do documentário, um conjunto de operações pelas quais registrávamos/documentávamos a presença ordinária dos velhos casarios e sobrados de Porto Alegre. Primeiro, desde a potência famulatória que eles nos despertavam, isto é, as estorias que eles pré-figuravam, as quais seriam (ou já estavam sendo), num segundo momento, refiguradas, por nós, em fato etnográficos extra-ordinários, por meio da imagem móvel e de seus dilemas, tendo em vista que no plano da refiguração aderimos as contrariedades da "fabula cinematográfica”. Ou seja, a imagem móvel que se organiza segundo o principio da identidade do ativo (da ação dada no

de contar uma história, (J. Rancière, La fable cinématographique, Paris, Seuil, 2001, em especial, La fable contrariée.

31 Aderimos ao conceito de fábula, no sentido da poética aristotélica, muthos, empregado por J. Rancière, La fable cinématographique, Paris, Seuil, 2001, como agenciamento de ações necessárias e verossímeis, ordenadas entre si pela linguagem e seus estilos, e segundo a qual os personagens vivenciam mudanças de sorte, no centro da qual o conceito de mimesis é central, não como mera imitação da ação, mas como representação, nos termos reconhecidos tanto por esse autor quanto por P. Ricoeur , Tempo e Narrativa, Petropolis, Papirus, 1994.

32 Conforme postula J. Racièere, La fable cinématographique, Paris, Seuil, 2001, p. 18, a arte estética opondo-se a arte representativa, em termos de regimes de artes diferenciadas, é aquela que permite ao cinema 
agenciamento dos conflitos de vontades e das ações, das mudanças de sorte) e do passivo (da passividade da escritura ótica, ao mesmo tempo, duplo do real e figura autônoma, liberada dos quadros da mimésis onde se origina).

Neste sentido, em nosso entendimento, as imagens etno-gráficas das ruínas, as "notas visuais de campo”, em parte, libertariam as moradas do viver, do agir e do sofrer humano que orientaram sua criação, compondo um espaço próprio, a ele retornariam, não mais visualmente, mas no plano da fabulação, não só como potencia da forma ativa, mas como domínio do imaginário. Os trabalhos para a construção de um pré-roteiro, de um roteiro para as notas visuais no trabalho de campo, tanto quanto do roteiro de edição, diante das coleções das imagens reunidas, sublinhava o "eu estive lá” 33 e sua carga de subjetividade, tão caro à tradição da autoridade etnográfica, tanto quanto marcava a distancia temporal do "eu estou aqui”, integrando-as do processo de objetivação do real.

Em decorrência, finalmente, adentraríamos a ultima dimensão da tríplice mímese, reconhecendo-se o conteúdo eufêmico das imagens móveis e do agenciamento entre elas: convidar o espectador a visitar o espaço fantástico que as ruínas evocam, no plano do imaginário, que, ao recebe-las, acaba por aderir as suas significações, configurando-as, por seu turno, como parte do instante de seu viver urbano (mescladas às imagens de suas lembranças, seus sonhos e suas ilusões).

Na ocasião, apostávamos na restauração da ação corrosiva do tempo como dinâmica da tessitura da intriga do documentário, e a chave interpretativa do problema da relação entre tempo "etnográfico" e a sua modelagem enquanto representação para o caso da formulação de uma narrativa etnográfica. Sob nosso ponto de vista, o processo de realização do documentário estaria atrelado ao encadeamento "lógico" entre os três modos de representar ou imitar uma situação passada por meio da imagem móvel e seus dilemas e contrariedades: o tempo prefigurado (campo da experiência pratica da etnografia visual que precede a tessitura da intriga), sua transformação num tempo refigurado (da experiência temporal ordenada segundo o roteiro do documentário construído) e, finalmente, pela mediação de um tempo configurado no momento de sua "leitura” pelo espectador.

Com isto afirmávamos a importância do conceito bachelardiano de pluralismo coerente (BACHELARD, 1960) para os estudos da imagem móvel (RANCIÈRE, 2001) segundo os estudos durandianos das estruturas antropológicas do imaginário (DURAND, 1984). Nestes termos, os princípios ativo e passivo da imagem móvel não podem ser pensados separadamente uma vez que ela, ao pretender operar com o tempo, opondo o mundo da matéria ao mundo do movimento, só consegue realizar esta façanha, contrariando seus princípios, através das artes de contar que

ser, ao mesmo tempo, "literatilização de uma idéia secular de arte e sua refutação em ato”, pois ele nasce da desfiguração romantica das historias” mas conduz esta “desfiguração” à imitação clássica”.

33 A moderna autoridade do trabalho de campo "estás ali porque eu estive ali”, cf. Clifford, J. in:

Reynosos, C. (org), El surgimento ...., op.cit. 
transformam o espaço fílmico, em distancia epidermicamente domesticada, autônoma, lugar onde o tempo pode ser re-encontrado.

\section{O tempo “etnográfico", a imagem móvel (crenças e mitos) e a modelagem da narrativa} etnográfica.

Com o intuito de investigar as feições do tempo presente nas formas da vida social no meio urbano portalegrense, o movimento dessas formas desdobradas e desenhadas nas suas ruínas - aqui entendidas como princípio da "unidade estilística" da vida citadina local -, optou-se por integrar a forma presente do passado das edificações ao processo de produção da imagem móvel- , atentandose para o atual da sua vida pretérita como objeto privilegiado de uma etnografia da duração. Da unidade da imagem exterior das ruínas dos casarios e sobrados em ruas e avenidas de uma cidade moderna, passaríamos para a ação interior de refletir sobre a totalidade do instante presente, retornando a elas na forma como a narrativa iria articulando em si mesmo o passado e o presente, desde as ponderações do futuro da metrópole.

Tendo como eixo condutor a concepção de pesquisa antropológica no contextos das modernas sociedades complexas por meio das imagens em movimento, a produção do vídeo $A$ cidade e suas ruínas teria como intenção primeira, então, o aprofundamento, no âmbito das pesquisas do Banco de Imagens e Efeitos Visuais/BIEV, determinados experimentos etnográficos de escritas sonoras visuais desde as perspectivas simeliana da tragédia da cultura (SIMMEL, 1934) e bachelardiana da dialética do instante (BACHELARD, 1932 ).

Tínhamos como suposto que nos procedimentos de construção de uma representação operatória do real (PIAGET, 1945b, DENIS, 1975, 1979) a imagem móvel em J. Rancière no que tange ao documental, combinaria, em proporções variáveis, duas dimensões temporais em polêmica constante: a dimensão cronológica (dimensão episódica da imagem, referida a situação etnográfica dialógica desde onde ela emerge) e a não-cronológica (dimensão configurante do fragmento, graças a qual toda imagem móvel pode transformar os acontecimentos por ela capturados, numa história a ser posteriormente narrada), ou seja, aludindo-se-se com e através dela a totalidade temporal da qual se originou.

Em termos do pluralismo coerente entre as estruturas inteligíveis e sensíveis, a imagem móvel, em sua a arte de "imitar" o movimento do tempo, estaria sujeita aos mesmos constrangimentos que envolvem a produção de um "texto etnográfico", se considerarmos aqui o que comentamos anteriormente, sobre o lugar da imagem móvel no plano do “documental". Considerando-se que o "documental” da imagem em movimento detém o poder de re-apresentação dos "fatos" sociais a partir das propriedades do movimento de suas formas, na figuração de uma distancia domesticada e controlada, tendo em vista o espaço diegético (muthos/fabula) que orienta e conduz a estrutura narrativa no plano do espaço fílmico. 
Defendíamos, na experiencia de campo, que, em seu poder de traduzir mimeticamente as situações sensoriais e motoras presentes ao encontro etnográfico e de seus estados sucessivos, a imagem móvel (videográfica) nos conduziriam a integrar as ruínas como parte integrante do vivido humano, por duas vias. As imagens das ruínas produzidas ao longo do trabalho de campo do etnógrafo revelar-se-iam parte da potencia psíquica e social por meio da qual toda a imagem lembra o seu análogo.

Neste sentido, apostávamos que a imagem “documental” da ruínas em sua condição cenográfica, por não ser ficcional, nos possibilitaria problematizar, durante a pesquisa de campo, o real da representação do tempo a partir do qual vínhamos “fabulando” uma duração para a paisagem urbana da Porto Alegre. Sob este ângulo, levávamos em consideração que as imagens das ruínas por nós produzidas, ao longo da pesquisa, pertenciam a um certo regime de representação nos termos J. Rancière (2005), isto é, o gênero documental e de suas leis e meios expressivos, e, para o caso da Antropologia, o da etnografia, que tem a escrita como regime de representação "científica”.

Tratava-se, assim, de desenvolver algumas propostas de narrativas etnográficas sobre a memória coletiva no mundo urbano contemporâneo, explorando-se as tecnologias de produção de imagens em movimento, em diversas modalidades de documentos audiovisuais, comungando com as preocupações de alguns setores da antropologia pós-moderna. A inspiração era o convite de Marcus e Cushman $^{34}$ aos seus colegas antropólogos para submeter as convenções do gênero realista, em Antropologia, as diversas classes de experimentações de gêneros narrativos. O gênero realista para a construção de representação etnográfica por meio da escrita, segundo apontam tais autores, utiliza-se do conjunto dessas convenções (como ponto de vista, argumento, estilo, etc.) para projetar a ilusão de totalidade do mundo retratado. Disto tudo resulta que os conflitos e ambiguidades próprios das relações em campo acabam por ser neutralizados, precisamente o que não desejávamos para o caso da retórica a ser adota no documentário.

Neste ponto, concordávamos com alguns dos pós-modernos que ponderavam que tais artimanhas no campo da produção dos saberes e fazeres antropológicos eram arquitetadas no berço positivista, com a finalidade de garantir uma maior sensação de objetividade científica na escrita etnográfica, as formas de apreensão do mundo estudado e da obtenção de informações ficam, neste gênero, geralmente, ocultadas.

Obviamente, estamos aqui transpondo parte desta polemica para a pesquisa da representação etnográfica por meio da imagem móvel revendo o tema dos gêneros discursivos na oposição imagem-movimento e imagem tempo (DELEUZE, 1990) segundo as perspectivas que pensamos convergentes entre os regimes de representação (RANCIÈRE, 2005) e os regimes de imagens (DURAND, 1984), numa tentativa de refletir sobre o realismo da imagem móvel para a

$34 \quad$ Cf. Marcus, E. G.e Cushman, E.D., Las etnografias como textos. in: Reynoso, C. (org) El surgimento de la antropologia posmoderna. Barcelona, Gedisa, 1991. 
produção de documentários no âmbito de uma etnografia da duração - sobre isto, em articular, falaremos mais adiante!

Evidentemente, no trabalho de escritura etnográfica audiovisual com a imagem-ação (e as suas situações ótico-sonoras e sensório-motoras correspondentes), entretanto, algumas estratégias acabam por ser inevitavelmente reveladas, o que na escrita convencional oriunda do espaço livresco levaria mais tempo e seria percebido através de outros procedimentos formais, mais indiretos. Antes de tudo, a imagem-movimento, reuniriam, para nós, uma sinergia de figurações diversas da modelagem de estruturas espaço-temporais: o conjunto dos elementos e característica do quadro espacial representado (diegético)- tais como campo, fora de campo, plano fixo, plano em movimento, a profundidade de campo, etc.-, o dos elementos espaciais que o organizam (fílmico) elaborado, construído, projetado virtualmente no enquadre da tela para orienta o olhar do espectador e dos elementos semânticos (narrativo) e dos ritmos desde onde evoluem as historias narradas. A imagem-movimento traduziria, sinteticamente, numa unidade contraditorial, o encadeamento entre o tempo do mundo, objetivo, e o tempo vivido, subjetivo, sofrendo o espaço diegético e o espaço narrativo, os quais não se são possíveis sem participação de um dispositivo de projeção e recepção cinematográfico (espaço fílmico) no interior do qual se encontra o espectador (MORIN, 1984).

\section{A aparente banalidade da vida ordinária e a pesquisa etnográfica com imagens}

Para nós, na realização da pesquisa com imagens para o documentário A cidade e suas ruínas, a imagem-ação carregaria, assim, o "real” da banalidade cotidiana das ruínas no cenário urbano portalegrense - em conformidade com a imagem-ação, prolongamento da "situação sensóriomotora que tem por espaço um meio bem qualificado" (DELEUZE, 1990:14). Por outro lado, a imagem-ação, suscitaria, igualmente, com força e propriedade, o tratamento das situações-limites do nosso próprio olhar diante sobre a decomposição da matéria que nos provocam as imagens das ruínas - desdobrando-se num situação ótica e sonora desconectados dos espaços vividos que elas representam - “estabelecendo este espaço qualquer, seja desconectado, seja esvaziado” (DELEUZE, 1990:14).

Não compartilhávamos com a ideia da oposição entre imagem-ação e imagem-tempo, no sentido deleuziano de atribuir a primeira as situações sensório-motoras fortes da descrição realista tradicional que fundaria o nascimento do cinema (e que não apaga nem destrói a realidade objetal sensório-motora, bem ao contrário, reforça) e, a segunda, as situações (puramente) óticas e sonoras, comprometidas com "olhar imaginário" que faz do real algo imaginário, ao mesmo tempo, que por sua vez se torna real e torna a nos dar realidade” - imagem-tempo que caracterizaria o neo-realismo (italiano) e nouvelle vague (francesa), desde a crise da imagem-ação para a linguagem cinematográfica contemporânea. (DELEUZE, 1988:18). Voltaremos a este ponto mais adiante, discordando do autor em sua abordagem do imaginário, principalmente, no uso que faz dele e do 
conceito de imagem e representação para a construção das oposições que cria entre imagem-ação e imagem-tempo para a narrativa cinematográfica, e em seus esforço de liberar a imagem fílmica de uma espaço de representação do vivido em prol de um espaço vazio e desertado, que, ironicamente, desde esta condição seria plenamente habitado pelo "ser ausente tanto para o mundo quanto para si”.

Entretanto, desde já adiantamos, nossa discordância desta abordagem bergsoniana do autor em que as situações óticas e sonoras puras, cindidas em dois polos (o objetivo e subjetivo, real e imaginário, físico e mental), se comunicariam, num sentido e noutro, segundo a "força estética" do seu “objetivismo crítico” (DELEUZE, 1988:.19), como resultado do afrouxamento, no plano da imagem, dos vínculos sensório-motores ou sua inibição! A importância de se reconhecer não só que a imagem ótica e sonora pura, imagem-tempo está a serviço da imagem-ação, no sentido de que ela para se realizar depende de um sistema de evidências sensíveis (RANCIÈRE, 2005). Trata-se de reconhecer que a imagem ótica e sonora pura, ao abordar a presença do sensível no inteligível, ou seja, como "cristais do tempo", só se realiza desta forma ao se afastar da vida (em sua busca frenética de destemporalizar o tempo), e, por isto mesmo, e que só adquire sentido só adquire o realismo moderno (e sua polemica entre cultura subjetiva e cultura objetiva, nos termos simelianos), e falsamente associado aos atributos das artes mecânicas.

Segundo o ponto de vista que adotávamos para produção da vídeo-pesquisa A cidade e suas ruínas, o documentário etnográfico não se reduziria, no plano documental, a uma simples "concepção predicativa do saber em termos de um conjunto organizado de enunciados" (passado, presente, futuro), ao contrário, ele se caracteriza em traduzir o sentido de um "saber-fazer" singular que surge como atividade humana duradoura(antes, durante e depois), face à situações vividas particulares que vivianos durante o trabalho de campo.

A "escritura" com a imagem em movimento - acrescida do som sincronizado que lhe é peculiar - transformava-se, assim, em possibilidade de construção de retratos etnográficos que a um só tempo desvendavam as formas como estes encontros com se tramam, as estratégias- intencionais ou casuais- de obtenção das informações e ainda revelar o exercício polifônico e heteroglótico no quais as relações sociais se estruturam. A imagem documental antes de ser considerada aqui em sua existência autônoma, apareceria como parte dependente da "fluidez" de toda a vida psíquica, nos termos caros a SIMMEL (1934), logo, portadora de valores indubitavelmente culturais. Nestes termos, estaríamos afirmando para o documental da imagem videográfica sua síntese entre um “desenvolvimento subjetivo e um valor espiritual objetivo”, sem rechaçar seu traço testemunhal como obra da cultura.

Seguíamos, assim, para a compreensão das ruínas para a paisagem da vida urbana, contemporânea, os estudos de P. Sansot (1991:b:74; 1990b:60) sobre a cidade em sua dimensão temporal cotidiana, do vivido humano, que nos permitia pensar o registro audiovisual como parte constituinte deste processo de sedimentação de uma memória coletiva nos corpos, nos gestos e nas 
falas de seus habitantes. Por intermédio das imagens da cidade captadas, por nós,descobríamos, na ambiência da cidade, os seus habitantes e como eles nos permitiam fabular sobre gestos, as intenções e as ações com as quais eles haviam atribuído a ela uma fisionomia. Das artes de fazer a intenção era levar a imagem documental a penetrar, mais lentamente, das camadas do tempo sobrepostas nas superfícies das ruínas dos antigos casarios de Porto Alegre, para as artes de dizer (DE CERTEAU, 1992), pela forma como, por meio delas, o corpo social tecia um destino para suas lembranças, impedindo, assim, de cair no esquecimento e se dissolver no tempo.

Nos movíamos, assim, no sentido contrário do ponto de vista deleuziano, ou seja, de que a imagem-tempo se contraporia a imagem-ação, uma vez que a banalidade cotidiana se revelaria na ausência de intriga. Aderindo a assertiva de que toda a vida humana merece ser narrada, e que todo a ordem do vivido humano pré-figura uma intriga, nossa intenção era dimensionar as leis ordinárias das distensão do tempo contida na imagem-ação que, segundo a perspectiva benjaminiana e simeliana, toda a caminhada pela cidade moderno contemporânea condensa. Contrariando a face moderna do cinema em sua intenção de ultrapassar a vida cotidiana e suas ligações sensóriomotoras, insistíamos, pela linha bachelardiana, na importância do encadeamento, denominado por G. Deleuze (1998:26) de fraco, entre as séries e sequências de ações para dar conta do espaço da representação fílmica do tempo desde a sua figuração nas ruínas, como duração.

Com isto, nos afastávamos do postulado deleuziano de que "tudo é ordinário e regular" (DELEUZE, 1998: 26) e para ser elevado ao estado "puro" do espírito, deve ser ser transmutado em espaço de vacuidade e desconexão, marcado pela ausência de conteúdo, para que assim, a imagem atinja sua feição de contemplação pura do tempo, do absoluto! Bem pelo contrario, aderíamos aqui a uma antropologia compreensiva em nossa intenção de atingir, pela imagem, o entendimento da estilização da ruína no cotidiano da vida urbana portoalegrense, feito de gestos, palavras, teatralidade, de obras minusculas ou maiúsculas (Maffesoli, 1985:30), como parte dos tesouros de sua memória coletiva.

Neste sentido, os caracteres das imagens comprometidas com a ação cotidiana e fortemente engajadas nas situações sensório-motoras, e nas quais se originam não é por esta razão, menos apta a o processo de conceituação do mundo das coisas que aquelas cujo registro tem por intenção a conquista de um espaço puramente ótico e sonoro, nem vice-versa! A combinação destas formas de representação imaginal em uma série de combinações e os processos de simbolização das feições do tempo por meio da imagem-movimento conduzia nossas preocupações de pesquisa. Ou seja, pensálas desde os processos de acomodação às situações sensório-motoras que acompanham o contexto da pratica da etnografia audiovisual, até a eleição, pelo etnógrafo, de certos padrões objetivos e concretos por meio dos quais a imagem subjetiva, captada pelo olho da câmera, se dá a ver o mundo na condição de representação, construindo-o como real! 
Sublinhávamos, com isto a proposta polifônica de encontro etnográfico, J. Clifford coloca “a etnografia não como uma experiência ou uma interpretação de “outra” realidade circunscrita, mas sim como uma negociação construtiva que envolve pelo menos a dois, e habitualmente a mais sujeitos conscientes e politicamente significantes”. ${ }^{35}$

Os elementos práticos, sensório-motores, da realidade imediata da ruínas para nós eram uma inspiração, e não um obstáculo a ser ultrapassado. Impossível atingir as feições do tempo que representa a ruína, como parte da tragedia da cultura (SIMMEL, 1934), sem dialogar com o mundo da memória que há no interior de sua matéria corporal, física, imediata, concreta, perfeitamente integrada as práticas do ordinário (DE CERTEAU, 1994), as ruínas por nós visitadas e captada em vídeo, em dialogo intenso e tenso com ambiência fervilhante das ruas e das avenidas, dos prédios de apartamentos e das lojas e casas de comercio, dos shoppings, etc. eram um convite a narração da fuga vertiginosa do tempo, um tempo que não escorre, mas se comprime. Neste plano do registro sonoro e visual da ordem do cotidiano pela imagem móvel, tínhamos claro que a imagem móvel e a situação sensório-motora de onde nasce poderia nos fornecer a forma expressiva da paisagem que a ruína manifesta. Não só, discordávamos da démarche deleuziana do cotidiano, mas nos contrapúnhamos a ela reunindo a perspectiva durandiana do trajeto antropológico do cotidiano na obra de M. De Certeau ( ).

Com isto pensávamos que o simbolismo do tempo poderia ser expresso na fábula videográfica, precisamente, pelo fato de, com ela, termos a preocupação de narrar a passagem do tempo desde a inteligencia narrativa própria a memória do cotidiano (DE CERTEAU, ), na qual manifestaria o trajeto antropológico (DURAND, 1984) que dá origem ao nascimento do simbolo e a construção do real (PIAGET, ). Imagem móvel, cotidiano, trajeto antropológico recolocam a imagem-ação em estreito dialogo, se pensarmos, na etnografia da duração, as imagens sensóriomotoras e as imagens óticas e sonoras puras faces da mesma aventura dos sujeitos da figuração diante da matéria do tempo. Figurar o tempo é já fabula-los, e vice-versa imprescindível, no plano de uma etnografia da duração, estar atento para a carga simbólica veiculada pela imagem móvel a qual nos permite refletir sobre as tensões existentes, ao nível do imaginário, entre o gesto pulsional do etnógrafo (de posse de sua câmera e microfone) e o meio material e social, aqui no caso, a cidade e as suas ruínas

\section{O espaço fílmico como reserva contra o tempo}

Primeiramente aceitamos, com J. Rancière ( 2001) que, no plano da narrativa da etnografia da duração, não se pode pensar o fracasso do pólo sensório-motor em acessar a imagem-tempo nem tampouco que aceitar o fardo de sua morte como expressão narrativa precisamente desde a sua passagem para o polo das situações óticas e sonoras puras, tal qual foi apontada por. G. Deleuze

35 Cf. Clifford, J. Sobre la autoridad etnográfica. In: Reynoso, C. (org.), El surgimiento ... op.cit. 
(1990:217) - deixando de ser cadeias de ininterrupta de imagens, 'escravas uma das outras'-, com base na teoria bergsoniana das relações que une a memória à matéria.

Tínhamos claro a importância significativa da obra deleuziana para a formulação da teoria do cinema moderno e sua influência sobre os estudos da linguagem cinematográfica no mundo contemporâneo. Ainda que o autor esteja se referindo ao tema do ficcional, e não do documental, entendiamos que parte dos equívocos de sua teoria, advindos de sua adesão irrestrita aos pressupostos bergsonianos do tempo, esta em que ele atribui, em referencia ao mestre, uma continuidade entre a "natureza" técnica da maquina da visão e as formas de arte cinematográfica, e disto deriva os estilos narrativos entre o cinema tradicional (imagem-ação) e o cinema moderno (imagem-tempo). Nossa perspectiva fenomenológica e compreensiva das relações que unem imagem, imaginário, máquina, tempo e equívocos desafiava a borrar as diferenças, propostas pelo autor, entre dois tipos de imagens (imagem-ação e imagem-tempo) desde a ótica dos estudos antropológicos sobre a cotidiano, memória coletiva e duração.

Ao se pretender, no documentário, A cidade e suas ruínas, uma etnografia audiovisual sobre os jogos da memória e a vida cotidiana nas grandes metrópoles contemporâneas, contrapúnhamos as ideias deleuzianas (e por derivação bergsoniana) de que existiria uma unidade "natural” da "imagem cinematográfica” no tratamento narrativo do fenômeno temporal uma vez que ela é fruto dos trabalhos da imaginação humana e de suas faculdades de produzir imagens (sejam elas mentais ou técnicas), participando assim dos processos arqueológicos, citados por A Leroi-Gouhran (1964), de liberação da memória, no seu desejo de transcender o tempo. Por esta via, tornava-se evidente que não aderíamos a ideia da existência de uma capacidade realista da narrativa cinematográfica clássica (para o caso do cinema ficcional o cinema-ação hollywoodiano), pois até mesmo nas imagens mais apegadas a carga simbólica das situações sensório-motoras da experiencia humana no mundo, encobrem o desejo humano de eufemizar as mudanças de estado do ser em deslocamento puro, na tentativa de que elas (as imagens), em sua homogeneidade, e livre da corrosão do tempo não seja por ele afetadas.

Outro ponto de discordância da perspectiva deleuziana era sua abordagem da autonomia da imagem-tempo, mais afeiçoada as situações ótica e sonora puras, uma vez que reconhecíamos nestas imagens, evidentemente, sua participação na ambivalência que caracterizam toda a representação imaginaria. As imagens puras, para nós, continuariam a ser imagens afetadas pelos lugares de onde vieram, e não imagens isoladas uma das outras, num espaço próprio, segundo a lógica da imagemcristal, uma vez que a vocação da imagem-cristal esta dada na vocação do sujeito pensante, participando assim de uma forma imaginária do espaço entre outras. Neste ponto, a intenção não foi apenas, ao seguir G. Bachelard (1989), E. Morin (1984) e G. Durand (1984,1989), reunir aquilo que o pensamento bergsoniano havia separado! Tratava-se de nos lançarmos num quadro de ruptura epistemológica com a taxinomia classificatória, no plano da imaginação criadora, da imagem 
técnica, em especial, para pensar o documental que toda a imagem contempla (sendo ela ficcional ou não).

Adotávamos a tese durandiana de que a imagem fílmica (ou qualquer outro tipo de expressão iconográfica, documental ou não) pela ocularidade e por seu caráter topológico é expressão de um espaço fantástico (DURAND, 1984; MORIN,1984), pois se traduz na representação de um agrupamento de coisas na forma de relações espaciais elementares. $\mathrm{Na}$ profundidade que ela carrega, toda imagem fílmica se revela espaço pensado, controle da distancia, abstração do tempo, uma vez que tal profundidade só é possível diante do fato de que o deslocamento e a sucessão se sobrepõe a simultaneidade das dimensões. Neste ponto, tanto a imagem-ação quanto a imagem-tempo se traduziriam como um convite as profundezas, a uma viagem distante.

Finalmente, pela homogeneidade que ela comporta, a imagem fílmica assegura um deslocamento "fora do tempo", ao reter a "fuga do tempo", ela pretende retardar sua ação, impedindo que aquilo que é registrado envelheça ou mude. Sob este ângulo, imagem-ação, imagemtempo expressão uma consolidação temporal onde o documental da imagem a situa no interior dos jogos da memória criados no âmbito das modernas sociedades complexas, o que nos permitiria compreender que nosso documentário A cidade e suas ruínas negaria este processo de desafeição da imagem do mundo das coisas, em sua intenção de desafeição das coisas elas mesmas, participando da ambivalência que caracterizaria toda a representação imaginaria, da qual o simbolo participa, e sem a qual o real da própria imagem não se constitui.

Segundo Jacques Rancière (2001), do olho cinematográfico da câmera, da dramaturgia maquina cinematográfica de Jean Epstein à metáfora do" cristal" de Gilles Deleuze, estamos tratando aqui da velha controvérsia da desfiguração da forma dividida entre o esplendor da pura atividade da ideia por detrás do conteúdo figurativo da imagem cinematográfica (suspenso em “cristais fabulosos”) e da presença sensível vida profunda e potência expressiva inscrita no encadeamento narrativo das coisas. Para este autor, a forma fixa na película, a situação ópticas e sonoras puras, unidade de forma e conteúdo na natureza técnica da imagem cinematográfica, fazendo coincidir dramaturgia plastica e dramaturgia ficcional (RANCIÈRE, 2001 : 21), produzem uma visão "não manipulada” das coisas.

A abordagem de J. Rancière nos permitiu pensar que o visível da situação narrativa e a ruptura do schème sensório-motor (PIAGET, 1945a, 1945b) resultado de um conjunto de operações, produto de uma "dramaturgia", marcada pelo caráter contraditorial de seus poderes, encerrando a imagem fílmica numa fabula da "vocação da maquina cinematográfica”. No cinema, o visível (e sua grande passividade) da imagem fílmica carrega uma "dramaturgia” atribuindo a “natureza” técnica da imagem uma significação narrativa. Para o autor, o cinema inverte o projeto da passividade do visível presente, por exemplo, imagem escrita, do romance e da literatura 
(RANCIÈRE, 2001 :22) uma vez que a “adição literária da imagem” se dá na substração de seu sentido, subtrair a letra do seu corpo, desapropria-la para lhe dar potencia de narração.

Os comentários deste autor sobre o cinema contrariando a literatura e o romance nos interessava de forma particular, pois, ao enveredarmos na pesquisa com narrativa etnográfica a partir da imagem-movimento estamos nos distanciando do projeto da escrita antropológica clássica que toma o corpo da letra como seu referencial. Suas observações nos colocavam numa perspectiva em múltiplos planos desafiadora! Contrapor-nos a perspectiva deleuziana no tratamento documental das ruínas e encontrar outros pontos de ancoragem de nossa proposta de vídeo pesquisa, era deles o menor!

\section{As artes de contar, a fabula contrariada e os dispositivos técnicos da produção de} imagens visíveis.

Assim, o cinema (uma fabula contrariada) contraria o texto a partir de duas visibilidades: a sensorialidade das imagens moveis, por um lado, e fragmentação visual, por outro (RANCIÈRE, 2001 :25). Disto resultaria a controversa entre o jogo narrativo das intrigas e jogo visual, por derivação, daquilo que na imagem existe de documento e o que ela carrega de ficção, e, por fim, a oposição entre obra engajada e obra pura ou, ainda, arte representativa (logica da ação) e arte estética (efeito do real). Momento em que as preocupações deste autor convergiam com nossas preocupações em precisar a adoção metodológica das notas visuais para a pesquisa com as ruínas, o tempo e a duração em Porto Alegre. Na leitura cuidadosa dos comentários de J. Rancière, encontrávamos apoio para restaurar o dialogo entre o cinema narrativo (dedicado ao encadeamento dos gestos e das percepções, nas ações dos personagens, numa atenção especial a restauração dos esquemas sensório-motores que dão sentido as suas ações) e o dito cinema puro (preocupado com a substração de ambos, substituindo a procura do restauro de tais esquemas pelo e no contraste entre ambos, na criação de dois espaços perceptivos) Com o autor, podíamos ensaiar a interpretação antropológica da perspectiva deleuziana da imagem-tempo como curiosamente afastada da vida”, ${ }^{36}$, ou seja, os “cristais do tempo"37. implicam na neutralidade da voz narrativa que necessita ser desnaturalizada, no automatismo da imagem-ação, precisaria ser desmembrado, revelado, denunciado, com a a voz humana até mesmo recortada do visível da sua figura ${ }^{38}$; os contra

36 Cf. A Freitas O sensível partilhado: estética e política em Jacques Rancière. In: História: Questões \& Debates, Curitiba, n. 44, p. 215-220, 2006. Editora UFPR

37 Para o pensamento deleuziano encontramo-nos numa oposição entre dois tipos de descricao: uma, organica, que prolonga na reação do personagem, (esquema sensorio-motor e agente de abstração, encadeando uma imagem-percepcao numa imagem-acao) e a outra outra fisico-geometrica, inorganica (eleva a imagem a raridade do que retem, seu modo de reconhecimento nao se prolonga en movimento, mas entra em relacao com uma imagem-lembranca).

38 O tema da imagem sonora no documentario A cidade e suas ruínas segue um percurso especial no interior da realização do vídeo-pesquisa, 
movimentos da câmera afetando o encadeamento das ações mais do que lhe fornecendo sentido; a apresentação da imagem-móvel como encenação de uma encenação, todas estas observações remetem a fabula cinematográfica e as suas contradições no interior do regime estético das artes onde o cinema se pretende anunciar seu status como arte.

No contraste entre o cinema ficcional e o cinema documental, admitíamos com o autor que este ultimo, pelo fato de não ser obrigado a produzir o sentimento de real, o filme documentário teria o privilégio de tratar este real como problema e experimentar os jogos variáveis as ações e da vida, do que significativo e do insignificante (RANCIÈRE, 2001 :26). Na fabula cinematográfica, ao contrário, a imagem que fala e a imagem que cala, a palavra que faz imagem e a que produz enigmas, ou seja, as artes das imagens e seu pensamento, não param de se alimentar daquilo que a contraria (RANCIÈRE, $2001: 28$ ). ${ }^{39}$

Seguindo a inspiração do momento, tratava-se, assim, de tencionar, desde o processo de captação das imagens em campo a processo de realização de um documentário etnográfico, a divisão deleuziana da imagem-ação a imagem-tempo e suas disjunções correlatas. Por um lado, trata-se de descartar a ideia da imagem documental em vídeo como imagem análoga do esquema sensóriomotor e a lógica de sua organização "natural” em conjuntos, segundo o encadeamento das percepções e ações, e por outro, o evitar o tratamento dessas imagens pela montagem, como imagens óticas e sonoras puras, oriunda da ruptura das imagens com a logica de tais percepções e das ações, e onde cada imagem separando-se das outras, encadear-se-iam entre si desde a ausência dos laços que as unem.

Do ponto de vista narrativo pretendíamos averiguar se, na etnografia da duração, a imagem videográfica , na herança da imagem-cinematográfica modernista, deveria realizar a passagem de um tipo de imagem a outra, no sentido de libertar a imagem do mundo físico do movimento, da matéria (imagem-ação) para os jogos da memória (imagem-tempo). Estávamos nos debatendo se, no tratamento narrativo do documentário, haveria “mais memória” para se narrar no efeitos incorporais que separam as imagens uma das outras (inertes elas próprias pois lembradas desde suas potencialidades) ou nos tempos cronológicos das coisas que estas imagens carregam desde suas propriedades perceptivas.

\section{Imagens sem metáforas?}

Em uma abordagem fenomenologia da imagem, G. Bachelard nos alerta para a sua importância em termos de ligação e a construção dos pensamentos, como parte integrante do rico psiquismo da imaginação criadora. Atentos as suas recomendações a respeito da dinâmica imediata

39 O tema da redução das artes de contar aos dispositivos tecnicos da produção de imagens visiveis e o tratamento da imagem sonora para o documentario não foi possível trazer para o debate no corpo deste artigo e certamente mereceria um ensaio à parte. 
que toda a imagem - "acontecimento do logos" (BACHELARD, 1993 :7) contempla, enveredamos para o exercício etnográfico em torno da imagem da ruína como parte do movimento da alma daqueles que a habitaram. E na sua dimensão de consciência poética do tempo, intentamos percorrer os desafios de operar com as imagens captadas pelo etnógrafo em campo não como mero substituto de uma realidade sensível, mas fenômeno que constitui o domínio de uma "memoria poetizada", tanto do registro do encontro do etnógrafo com a ruínas, quanto do registro da partilha das narrativas sobre as ruínas com aqueles que nelas habitam. Para o pensamento deleuziana, ao contrario,, "na banalidade cotidiana a imagem-ação, e mesmo a imagem-movimento tendem a desaparecer em favor de situações ótica puras, mas estas descobrem ligações de um novo tipo, que não são mais sensóriomotoras, e pões os sentidos liberados em relação direta com o tempo,com o pensamento" (DELEUZE, 1998:28)

Diferentemente de Bergson e, por derivação, afastando-nos da perspectiva deleuziana, a natureza da imagem, em seus jogos de fantasia, não designa a imagem da natureza da imaginação, uma vez que a imaginação se traduz como a faculdade de produzir imagens que se destacam do passado, da natureza e da imediatez do mundo das coisas. Reunimos, assim por esta via, ambas as representações da imagem-movimento e suas assertivas. Por esta via compreensiva, as imagens que procuram retraçar as situações sensório-motoras de onde se nutrem, quanto aquelas situações ótica e sonora puras, em seus esforços de esvaziar o espaço fílmico de suas qualidades, numa redução eufêmica do espaço em deslocamento puro, naquilo que nem dura, nem é afetado pelo tempo.

A lógica do vazio e do pleno para o espaço fílmico, contrariando a perspectiva bergsoniana, e adotada para o documentário em nossa investigação sobre o tema da ruína, tempo e duração, nos distancia da perspectiva deleuziana do cotidiano, entendido como fenômeno regular e ordinário, e contemplado desde as ligações sensório-motoras fracas que fornece no plano da construção da imagem. No movimento de câmera apostávamos precisamente na aparente desconexão do vai e vem da ruína de uma casa para outras casas, em ruínas, carregando esta paisagem ruinosa uma pergunta que uniriam os mortos aos vivos. Tínhamos como intenção ir do espaço vazio dos interiores, desprovido de personagens e movimento, aos espaços plenos de movimento e ruídos, nunca “imagens por inteiro e sem metáforas” (DELEUZE, 1998:31), pois reconhecíamos nas imagens reunidas em nossas notas visuais forte carga simbólica. Tínhamos em mente que o tempo para ser duração não pode ser precisamente a "duração daquilo que permanece, através da sucessão de espaços mutantes”, nem mesmo "forma imutável daquilo que se move”. Impossível pensar que as notas visuais de campo detenham esta "condição de permanência”, nem sequer que possam ser abordadas como imagens puras e diretas do tempo, Kronos. ${ }^{40}$

$40 \quad$ Cf. Antonioni, “L’horizon des évènements”, Cahiers du cinéma, No 290, jul. 1978, p.11 “o tempo como "reserva visual dos acontecimentos em sua justeza", citado por (DELEUZE, 1998:28), como "forma 
Discordávamos do autor quando afirma que "uma situação ótica e sonora não se prolonga em ação, tampouco é induzida por uma ação”, e onde o autor, contradizendo todos os estudos da psicologia da inteligência piagetiana, e pós-piagetiana, assinala que não se extraí conhecimento “das relações sensório-motoras da imagem-ação”, apenas reconhecimento; ou quando menospreza a imagem sensório-motora denominando-a de clichê, por ser de "natureza afetiva", em relação a imagem pura, “inteira e sem metáfora”, que faz surgir a coisa em si mesma” (DELEUZE, 1998: 31). Sua adoção irrestrita ao mestre o leva negar os debates e embates da epistemologia genética (PIAGET, 1978a. 1978b) da fenomenologia e G. Bachelard (1989a) com a perspectiva bergsoniana da imaginação, da memória em suas relações com a matéria, . Assim como, caminhamos no sentido contrário da afirmação do autor de que a vida cotidiana, dos gestos do mundo subterrâneo, guarda em si mesmo valores tradicionais e até mesmo reacionário.

Rarefazer a imagem, introduzir vazios na imagem, suprimir dela coisas que lhe foram acrescentadas, entretanto, parecem não convencer o autor sobre suas próprias ideias a respeito do reversão, em termos cognitivos, que a imagem ótica e sonora pura representa em relação a imagemmovimento e seus signos sensório-motores. Nesta ultima, o tempo (subjetividade pura) apareceria como a medida do movimento (pura exterioridade), na primeira, o movimento (a matéria puramente espacial) aparece como sendo a medida do tempo (matéria do espirito). Tínhamos como certo e seguro que o pensamento deleuziano cumpria à risca a dicotomia bergsoniana dos laços entre matéria e imaginação, segundo a a subjetividade pura (o espírito) versus a pura exterioridade (a matéria), em que a primeira filia-se a memória e a segunda, a percepção, e para a qual o tempo se qualifica sob duas formas distintas, em mecanismos sensório-motores e em lembranças independentes $^{41 .}$

Ignorando incondicionalmente, os estudos estudos piagetianos da representação de sua própria época e suas pesquisas que sustentam a ideia de uma "coerência funcional” entre o pensamento simbólico e o sentido conceitual, e da qual resulta a unidade e a solidariedade de todas as formas de representação, e repisando a incompletude do pensamento de seu mestre que sustenta a dicotomia entre a memória hábito e a memória lembrança, ou a pura memória e a memória-imagem, temos, assim, em G. Deleuze a ideia de uma imagem ótica e sonora pura, a imagem-tempo por oposição a imagem sensório-motora, imagem-ação.

Pensando os constrangimentos perceptivos e sensoriais da rapina do tempo, apostávamos que, pela via das notas visuais de campo, a imagem documental dos casarios e sobrados em decomposição - abandonadas ou temporariamente habitados por seus guardiões - como parte de exercícios de manipulação experimental sensório-motora do etnógrafo na cidade, guardaria consigo

inalterável preenchida pela mudança”. Segundo a perspectiva deleuziana, o durável e o mutante como, um só e mesmo tempo como forma imutavel daquilo que muda"(DELEUZE, 1998:28).

$41 \quad$ Seguimos aqui BERGSON 1990; BOSI 1987 e BORELLI 1992. 
o acontecimento do seu encontro etnográfico as feições do tempo. As notas visuais teriam como propriedade o fato de integrar a atividade mnemônica ${ }^{42}$ do etnógrafo em campo, do jogo de mediação imaginal que o une ao objeto etnografado e do sistema de codificação por ele acionada através do registro audiovisual. Compartilhávamos com G. Durand (1984:475) a assertiva de que mesmo o super-espaço euclidiano, um espaço de homogeneidade ilimitada, sem profundidade e sem leis, sem planos sucessivos, que não é afetado por nenhuma deformação física, sequer a corrosão do tempo, por suas propriedades fantásticas, é também “traído” pela percepção sensório-motora e de sua "mescalinização".

Nossa intenção não era, portanto, aderir a sobriedade do "moderna” da imagem que, para a imaginação deleuziana, congela e cristaliza o tempo, detendo a sua matéria perecível numa “imagem puramente visual do que é um personagem, e da imagem puramente sonora do que ele diz" (DELEUZE, 1998:24). Tínhamos claro que, isto posto, paradoxalmente, a imagem-movimento se tornaria atemporal, não podendo com isto fornecer nenhuma interpretação sobre a memória, o tempo e a duração. Sob este ângulo, a ruína nada nos ensinaria a respeito da função simbólica que organiza o espaço perceptivo como espaço da representação ${ }^{43}$ (PIAGET, 1948), ou seja, no plano do imaginário, como ação interiorizada da tragicidade do tempo na matéria terrestre.

Diferentemente das críticas deleuzianas à imagem-ação, apostávamos precisamente na balada e na perambulação como parte dos movimentos de câmera de uma etnografia capaz de retirar a ruína de sua indiferenciação, enganchando sua imagem num pertencimento a um lugar. Os movimentos de câmera ao invés de serem rarefeitos, no documentário aparecem em profusão, "pans” extremamente lentas, os travellings aderindo ao solo e a câmera na mão se contrapõem a idéia de planos fixos, verdadeiros "blocos de cimentos", assim como a doxa da câmera fixa e frontal. Da mesma forma, nas notas visuais obtidas em campo, abusávamos das fusões de todos os tipos em detrimento corte e dos cânones da montagem cut, concebida, segundo a imaginação deleuziana, a partir da pontuação ótica entre imagens. nas notas visuais obtidas em campo.

Se para G. Deleuze (1998: 23), com base na sua adesão a perspectiva bergsoniana, as "séries e sequências só nos aparecem em pequenas partes, e num ordem remexida e misturada, de modo que acreditamos em rupturas, disparidades e discordâncias como coisas extraordinárias”, para G. Durand (1984) as séries e seqüências participam ordinariamente da significação imaginaria da forma do tempo como duração, pela força simbólica que que comporta toda a (re)presentação contempla, capaz de fazer a ação corrosiva do tempo se depreender de seu conteúdo imediato, para ser redescoberto na continuidade de uma sucessão.

42 Apoiamos aqui nos comentários sobre as formas de representações por imagens, a atividade mnésica e o tema da cognição de Michel Denis, Représentation imagée et activité de mémorisation. Paris, CNRS,1975, p.21.

$43 \quad$ A respeito Jean Piaget. La représentation de l'espace chez l'enfant. Paris, PUF, 1948, pp. 532-535. 
Neste sentido, subvertemos as denominações deleuzianas, ao sustentarmos que a imagemtempo,e seus signos óticos e sonoros puros, é vibração tanto quanto a imagem-ação, e seus signos sensório-motores, é hesitação! Nem uma, nem outra, expressam a relação da imagem com uma realidade imediata, pois para se consolidar em séries que se compõem e convergem de forma regular, ambas obedecem as leis "ordinárias” de uma fantástica transcendental, da qual toda a imagem, até mesmo a mental, participa.

\section{Referencias}

BACHELARD, L'Eau et les rêves. Paris, Librairie José de Corti, 1942.

BACHELARD, G. La dialectique de la durée. Paris, PUF, 1989a.

BACHELARD, G. La poétique de l'espace. Paris, PUF, 1989b

BACHELARD, G. La poétique de la rêverie. Paris, PUF, 1993.

BACHELARD, G. L'intuition de l'instant. Paris, Editions Gonthier, 1932.

BACHELARD, G. La terre et les rêveries de la volonté. Paris, José Corti, 1988.

BACHELARD, G. La terre et les revêries du repos. Paris, José Corti, 1988.

BACHELARD, La formation de l'esprit scientifique. Paris, Librairie Philosophique J. Vrin, 1940.

BERGSON, H. Essai sur les données immédiates de la conscience. Paris, PUF, 1970.

BERGSON, H. L'évolution créatrice. Paris, PUF, 1959.

BERGSON, H. La pensée et le mouvant. Essais et conférences Paris, PUF, $1969 b$.

BERGSON, H. Matiére et Mémoire. Essai sur la relation du corps à l'esprit. Paris, PUF, 1969.

CARDOSO DE OLIVEIRA, Roberto. O trabalho do antropólogo. Brasília: Paralelo 15, São Paulo: Editora UNESP. 2000.

CASSIRER, E La philosophie des formes symboliques. Vol. I, II III. Paris, Editions de Minuit, 1972.

CHARTIER, Roger. Práticas de leitura. São Paulo: Estação liberdade. 1996.

CHARTIER, ROGER. Culture écrite et société. Paris: Albin Michel. 1996a.

CHARTIER, ROGER. A aventura do livro, do leitor ao navegador. São Paulo: UNESP. 1999.

CLIFFORD, James. On the authority ethnographic. In: Representations, vol. I, $\mathrm{n}^{0}$ 2, 1983, p. 117-146.

De CERTEAU, Michel. A escrita da História. Rio de Janeiro: Forense Universitária. 2002.

De CERTEAU, M. A invenção do Cotidiano. Patropolis, Vozes, 1992.

DENIS, M. Les images mentales, Paris, PUF, 1979.

DENIS, $M$. Representation imagée et activité de mémorisation, Paris, Editions du CNRS, 1975.

DURHAN, E. A dinamica da cultura. São Paulo, Cosac \& Naify, 2004.

DURHAN, E. A caminho da cidade. São Paulo, Ed. Perspectiva, 1984.

DURAND, G. Beaux-Arts et archétypes, la religion de l'art, Paris PUF, 1989.

DURAND, G. Figures mytrhiques et visages de l'oeuvre. Paris Berg International, 1979.

DURAND, G. Les structures anthropologiques de l'imaginaire, Paris, Dunod, 1984.

DURAND,G. L'imagination symbolique, Paris, PUF, 1992.

DURAND, Gilbert. Science de l'homme et Tradition. Paris: Berg. International. 1979. 
DURAND, Gilbert O imaginario. Ensaio acerca das ciências e da filosofia da imagem. Rio de Janeiro, DIFEL, 1998.

ECKERT, Cornelia \& ROCHA, Ana Luiza C. da “ A interioridade da experiencia temporal do antropólogo como condição da produção etnográfica”. In: Revista de Antropologia. Departamento de Antropologia. Faculdade de Filosofia, Letras e Ciências Humanas. Universidade de São Paulo/USP. São Paulo, SP. Vol.41 n. 2, 1998.

ECKERT, Cornelia \& ROCHA, Ana Luiza C. da "Filmes "de” memória, do ato reflexivo ao gesto criador”. In: Ciência \& ambiente. Universidade Federal de Santa Maria. Santa Maria, Rio Grande do Sul, Ed. da UFSM. Vol. 1, n. 18, jul. 1999.

ECKERT, Cornelia \& ROCHA, Ana Luiza C. da “ Os jogos da memória”: In: ILHA, Revista de Antropologia. PPGAS/UFSC. Florianópolis, SC, Ed. UFSC. Vol.2, n.1, dezembro 2000.

ECKERT, Cornelia e GODOLPHIM, Nuno (orgs). In: Horizontes Antropológicos, Antropologia Visual. Porto Alegre, PPGAS/UFRGS e Ed. da Universidade, 1996. FERRY, L Homo Estheticus, línvention du goût à l’âge démocratique. Paris, Grasset, 1990.

GEERTZ, Clifford. Nova luz sobre a Antropologia. Rio de Janeiro: Jorge Zahar Editores. 2001.

GEERTZ, Clifford. Obras e vidas, o antropólogo como autor. Rio de Janeiro: Editoria UFRJ. 2002.

MAFFESOLI, Michel. Aux creux des apparences, Paris, Plon. 1990.

MAFFESOLI, Michel. La connaissance ordinaire, précis de sociologie compréhensive. Paris, Librairie Méridiens. 1985.

MAFFESOLI, Michel. La conquête du présent. Paris, PUF. 1979.

MARCUS, George E. \& Cushman, Dirck. Ethnographies as text. In: Annual Review of Anthropology, v. 11, 1982. p. 25-69.

GUÉNON, R. La Régne de la Quantité et les signes du Temps . Paris, Gallimard, 1972.

GUÉNON, R. Orient et Occident. Paris, Ed. De la Maisnie, 1987.

LEROI-GOURHAN, A Le geste et la parole. Vol I e II.. Paris, Albin Michel, 1964.

MORIN, E. Le cinéma ou l'homme imginaire. Paris, Editions Minuit, 1984.

PIAGET, J. Estudos Sociológicos, Barcelona, Ariel, 1997.

PIAGET, J. A Epistemologia Genética, SP, Abril Cultural, 1978a.

PIAGET, J. Sabedoria e Ilusões da Filosofia, SP, Abril Cultural, 1978b.

PIAGET, Jean. O nascimento da inteligência na criança, RJ, Zahar, 1970.

PIAGET, J. La formation du symbole chez l'enfant. Delachaux et Nieslé, Neuchâtel-Paris 1945a.

PIAGET, J. La construction du réel chez l'enfant. Delachaux et Nieslé, Neuchâtel-Paris 1945b.

RANCIÈRE, Jacques. Políticas da Escrita. São Paulo: Editora 34. 1995.

RANCIÈRE, Jacques. A partilha do sensível. São Paulo: Editora 34. 2005.

RANCIÈRE, Jacques. O desentendimento. São Paulo: Editora 34. 1996.

RICOEUR, Paul. Tempo e Narrativa., Volumes I, II e II. São Paulo, Papirus, 1994

RICOEUR, PAUL. O SI-MESMO COMO UM OUTRO, SÃO PAULO. PAPIRUS, 1991.

ROCHA, Ana Luiza C. da “ A irracionalidade do belo e a estética urbana no Brasil”. In:

Territórios do cotidiano, uma introdução a novos olhares e experiencias. Zila Mesquita \&

Carlos Rodrigues Bradão (orgs). Porto Alegre/Santa Cruz do Sul, Rio Grande do Sul, Ed. da UFRGS/Ed. da UniSC, 1995.

ROCHA, Ana Luiza C. da "Antropologia visual, um convite à exploração de encruzilhadas conceituais”. Cornelia e MONT-MÓR, Patrícia (orgs). In: Imagem em foco, 
novas perspectivas em Antropologia. Porto Alegre, PPGAS/UFRGS e Ed. Da Universidade, 1996.

ROCHA, Ana Luiza C. da “ Antropologia das formas sensíveis: entre o visível e o invisível, a floração de símbolos”.

SIMMEL, Georg. Cultura femenina y otros ensayos. Madrid: Revista de Occidente. 1935.

SANSOT, P. Les gens de peu, Paris, PUF, 1992.

SANSOT, P. Le goû de la converstion, Paris, Desclée de Brouwer, 2003.

SANSOT, P. Les formes sensibles de la vie sociale, Paris, PUF, 1986.

SANSOT, P. Poétique de la ville, Klinckieck, Paris, 1997.

SANSOT, P. Variations paisagères, Paris, Klincksieck, 1983.

SIMMEL, G. “A metrópole e a vida mental”. In: Sociologia urbana. VELHO O (org). Rio de Janeiro, Zahar Editores, 1979. 